\title{
VERMINDERING VAN DE WAARDE VAN HET GELD DOOR DE GOUD-PRODUCTIE.
}

\section{(Ingezonden.)}

Het zoo gunstig verschijnsel van de als wonderdadige productie van het goud in de laatste jaren, 't welk reeds voorlang de aandacht en onderzoekingen der staathuishoudkundigen bezig hield, wint hoe langer hoe meer in de algemeene belangstelling, naarmate zijn gevolgen zich op praktisch gebied, in het onderling verkeer en op het bijzonder vermogen, meer en meer beginnen te doen gevoelen. Hoogstbelangrijke artikelen wijdde de beroemde Michel Chevalier voor eenige weken in het Journal des Débats an dit onderwerp, een onderwerp voor Frankrijk van nog te gewigtiger gevolgen, naardien zij zich dáár ook onmiddelijk voor den staat moeten doen gevoelen vermits er, zoo al niet regtens dan toch feitelijk, nog de dubbele standaard in het muntstelsel aanwezig is. En mogen nu al die bepaalde kwestie in ons vaderland ten voordeele van den staat reeds in 1847 zijn uitgemaakt, het onderling verkeer, het bijzonder vermogen, zal ook hier even als elders den invloed van het versehijnsel ondervinden.

Het mag daarom niet onbelangrijk zijn hier een ander, dezer dagen is hetzelfde Journal voorkomend, artikel te vermelden, waarin de aandacht gevestigd wordt op eene ontwikkeling van het gevaar, dat ex roor godshuizen en instellingen van liefdadigheid uit de waardevermindering van het geld kan voortvloeijen, door den Heer Chardes Lucas in de Académie des Sciences Morales et Politiques voorgedragen.

De herinnering aan het verledene hetwelk in gelijke omstandigheden de nadeelige gevolgen daarvan zoo duidelijk voor oogen stelt, wordt vooreerst ingeroepen om deze ook voor het tegenwoordige aumschouwlijk te maken. Met het oog daarop, wijst de Heer 
Lucas aan de liefdadige instellingen haar redmiddel in onroerende bezittingen in tegenstelling van die van staatsschulden. Hij tracht aan te toonen, hoe nadeelig de gevolgen zullen zijn van de maatregelen, welke die instellingen gedwongen hebben, hunne gelden in staatsschulden te beleggen. Haar bestaan wordt daardoor aan alle wisselvalligheden van de waarde van bet geld blootgesteld. De productie van het goud in Californie en Australie, vereenigd met de amortisatie van de staatsschuld, welke men berekent dat eenvoudig door de natuurlijke en onvermijdelijke waardevermindering van het geld, de tijd alleen te weeg brengt, moet, zijns inziens, den ondergang der liefdadige instellingen ten gevolge hebben. $\mathrm{Hij}_{\mathrm{ij}}$ waarschuwt daarvoor tegen de aanlokkelijkheden, welke een hoogere interest, de hoop op eene vermeerdering van het kapitaal, en nog andere voordeelen, als onvatbaarheid voor beslag, vrijdom van belasting, mogen aanbieden om de belegging in stantsschuld te bevorderen; waartoe men thans te eer geneigd is, naarmate de vroegere weêrzin geweken is. Hij vreest, dat men, getroffen door het dadelijk voordeel, alleen daarop het oog vestige, en het sluite voor de nadeelen die, meer verwijderd, de keerzijde van de medaille vertoonen, de wisselvalligheden n. 1., waaraan de staatsschuldeischers zijn blootgesteld door de waardevermindering van het geld. Men offere het toekomende niet aan het tegenwoordige op. Die toekomstige gevaren zijn voor de instellingen van weldadigheid veel grooter dan voor particulieren. Terwijl toch de eerste van de staatsschuld een vaste geldbelegging maken, en derhalve gedwongen zijn alle gevolgen der waardevermindering te ondervinden, kunnen dairentegen particulieren zich voor een groot deel daartegen vrijwaren, door dien zij, vrijer in hunne bewegingen, staatsschulden koopen en verkoopen wanneer hun dit goeddunkt.

Zoo komt de Heer Lucas tot het besluit dat godshuizen en liefdadige instellingen grooten prijs moeten stellen op onroerende bezittingen. Evenzoo moeten echter alle huisvaders handelen en alle voorzigtige kapitalisten, die er niet op uit zijn om bij den dag de voordeelen te behalen, welke de speculatie op roerende waarden aanbiedt; allen eindelijk, die eene meer vooruitziende en verhevener ambitie hebben, en die het bestaan huns huisgezins willen verbinden aan iets, dat daaraan, althans voor een geslacht, het fortuin kan verzekeren. Het is goed, het is wenschelijk, zegt de Heer Lucas, daar die voorzigtige en geduld oefenende kapitalisten wel weten, dat de plaatsing van geld in die landerijen degene is, welke hun de meeste zekerheid en vastheid aanbiedt; de eenige, die in 


\section{8}

plaats van voor geld-revolutie te behoeven te doen vreezen, de waardevermindering van het geld, door de meerdere dnurte der voortbrengselen en pachten, te boven komt. En niet alleen ontgaat alzoo deze geldbelegging die waardevermindering welke de tijd alle andere waarde doet ondergaan, maar zelfs ontstaat hier een vermindering van rijkdom, door de verbeteringen welke de tijd langzamerhand meer voortdurend in 't leven roept, en welke men in den landbouw, reeds lang te voren met bekwaamheid moet voorbereiden en met geduld weten af te wachten.

De geld-crisis, welke alzoo niet alleen de liefdadige instellingen bedreigt, doet zich reeds drukkend gevoelen op de kleinere huishoudingen van die ambtenaren welke, van 1000 tot 1500 franken traktement genietende, zoo menigvuldig zijn in de verschillende takken van bestuur. Voor dezen acht de Heer LuCAs het oogenblik gekomen, dat zij meer in evenredigheid met de waarde van het geld beloond worden, en verlangt hij alzoo dringend dat humne traktementen verhoogd worden, naar gelang der vermindering van de geldwaarde om deze alzoo te brengen op de werkelijke waarde, welke zij vertegenwoordigden op het oogenblik dat zij werden rastgesteld. Hij hoopt en twijfelt niet of de staat zal, niettegenstaande de overgroote oorlogslasten, nog wel in staat zijn, om in dit belang, dat zich door regtvaardigheid en billijkheid ten hoogste annbeveelt, te voorzien.

's Gravenluge, Julij.

F.

Als voorbeeld van hooge belasting-betaling kan genoemd worden, Nich: Iongworth, van Cincinnati, in Noord-Amerika, die onlangs door een der dagbladen te Nienw-Orleans werd opgegeren voor het loopende dienstjaar, 30,328 dollars voor zijn aandeel in den incometax aan de schatkist te hebben betaald. - Dan de income-tax daar ter plaatse $3 \mathrm{pCt}$. van het inkowen bedraggt; zoo geeft deze betaling van 75,000 gulden 's jaars, een inkomen van $f 2,500,000$ te kennen. Benijdenswaardig voorregt, om zulk cen aanslag-biljet te ontvangen. 